\title{
The Proximate and Elemental Analysis of some Leafy Vegetables Grown in Minna and Environs
}

\author{
SAIDU, A.N; JIDEOBI, N.G. \\ Department of Biochemistry. Federal University of Technology, Minna. \\ E-mail:ansaidu@yahoo.com.
}

\begin{abstract}
Four different leafy vegetables grown and commonly consumed in Minna and it's environ was analysed with a view to determine the nutrient content of these vegetables. The vegetables are water leaf ( Talinum triangulare), fluted pumpkin ( Telferia occidentalis), bitter leaf ( Vernonia amygdalina) and drumstick ( Moringa oleifera).Among the four leafy vegetables, Talinum triangulare contains the highest amount moisture (91.6\%), Vernonia had the highest ash and lipid content $(2.5 \%)$ and $(0.7 \%)$ respectively. Moringa had the highest amount of protein $(2.9 \%)$. It is also the richest source of sodium while Telfeiria had the highest $\mathrm{K}^{+}$ion value. The results obtained in this work clearly indicates that the four leafy vegetables are cheap and readily available source of the nutrients.@JASEM
\end{abstract}

It is a fact that health is wealth. The health of an individual depends on the qualities and quantities of foodstuff he consumes. The food requirements are simply needed to supply the minimum requirement of the six groups of nutrients viz: carbohydrates, fats, proteins, mineral elements, vitamins and water (Alfred and Patrick, 1985). Vegetables contain nutrients which can be absorbed by the body to be used as energy sources, body building, regulatory and protective material. It is essential to prepare vegetables in a manner that will retain maximum amount of vitamin $\mathrm{C}$ because the vitamin is often lost before consumption through oxidation and leaching during preparations (Baker and Griffin, 1967). Leafy vegetables generally are comparatively rich in fiber while cereals, root vegetables and other foodstuff are relatively poor sources (Brain and Allan, 1982). According to Oke and Ojofeitmi (1988), vegetables, contain low calories and negligible quantities of utilizable energy hence they are ideal for obesed people who can satisfy their appetite without consuming much carbohydrates. Although there is low level of protein in vegetables, there is increasing awareness of the importance of vegetable in maintaining health, particularly in areas where animal protein is scarce (Baker and Griffin 1967). Moringa leaves are known as excellent sources of nutrition and natural energy booster. It lowers blood pressure and it's a sleep aid (Fugile, 2000). For pregnant and breast feeding woman, moringa leaves can do much to preserve the mother's health and pass on strength to the foetus (Price, 1995). The aim of this work is to determine the nutrient content of the selected leafy vegetables if they could be used as supplement to other scarce or no available source of nutrients.

\section{MATERIALS AND METHODS}

Fresh green leafy vegetable were obtained from markets in Minna and its Surburbs. The leaves were removed from the stem and damaged ones excluded. They were cut into pieces for analysis. Certain portions were oven-dried and kept in air-tight plastic containers for further analysis. Moisture, ash crude protein, lipid and carbohydrate analysis were carried out by modified methods of Oke, 1986 while vitamin $\mathrm{C}$ content was determined by titration method. Elemental analysis was determined by the use of flame photometer

\section{RESULTS AND DISCUSSION}

Table 1: Common and Botanical names, place of cultivation and \% composition of moisture, ash, lipid, protein, carbohydrate and vitamin C.

\begin{tabular}{|c|c|c|c|c|c|c|}
\hline Common Names & $\begin{array}{l}\text { Place of } \\
\text { Cultivation }\end{array}$ & $\begin{array}{l}\% \\
\text { moisture }\end{array}$ & $\%$ Ash & \% Lipid & $\%$ Protein & $\%$ Carbohydrate \\
\hline $\begin{array}{l}\text { Water leaf (Talinum } \\
\text { triangulare) }\end{array}$ & Tunga & $\begin{array}{l}91.6 \\
(90-93)^{*}\end{array}$ & 1.6 & $\begin{array}{l}0.4 \\
(0.4-1.0)^{*} \\
\text { Oke,1994. }\end{array}$ & $\begin{array}{l}2.52 \\
(0.4-3.0)^{*} \\
\text { Tindall,1988 }\end{array}$ & $\begin{array}{l}4.3 \\
(4.0-4.5)^{*} \\
\text { Oke, } 1984\end{array}$ \\
\hline $\begin{array}{l}\text { Fluted pumpkin } \\
\text { (telferiria occidentalis) }\end{array}$ & Bosso & 98.5 & 2.2 & $\begin{array}{l}0.3 \\
(0.2-2.0)^{*} \\
\text { Tindall, } 1988\end{array}$ & $\begin{array}{l}2.4 \\
(0.2-3.0)^{*} \\
\text { Tindall, } 1988\end{array}$ & 4.4 \\
\hline $\begin{array}{l}\text { Bitter leaf (vernonia } \\
\text { amygdalina) }\end{array}$ & Chanchaga & $\begin{array}{l}87.7 \\
(86-88)^{*} \\
\text { Sengupta, } \\
1980\end{array}$ & $\begin{array}{l}2.5 \\
(86-88) \\
\text { Sengupta, } \\
1980\end{array}$ & $\begin{array}{l}0.7 \\
(0.3-1.0)^{*} \\
\text { Sengapta, } 1980\end{array}$ & $\begin{array}{l}2.10 \\
(2.1-2.36)^{*} \\
\text { Sengupta, } 1980\end{array}$ & $\begin{array}{l}5.00 \\
(4.27-7.18)^{*} \\
\text { Sengupta, } 1980\end{array}$ \\
\hline $\begin{array}{l}\text { Drumisick (moringa } \\
\text { oleifera) }\end{array}$ & $\begin{array}{l}\text { FUT Minna } \\
\text { Campus }\end{array}$ & 87 & 2.4 & 0.2 & 2.9 & 4.5 \\
\hline
\end{tabular}


Table 2: Mineral Composition of the leafy vegetables studied.

\begin{tabular}{llll}
\hline Common Names (Botanical names) & $\mathrm{Na}^{+}(\mathrm{ppm})$ & $\mathrm{K}^{+}(\mathrm{ppm})$ \\
\hline Water leaf (Talinum triangulare) & $0.4300 \quad * *(\mathrm{RDI}-2400 \mathrm{mg})$ & 0.7123 & $* *(\mathrm{RDI}-3500 \mathrm{mg})$ \\
Fluted pumpkin (Telferia occidentalis) & 0.4215 & 0.8721 & \\
Bitter leaf (Vernonia amygdalina) & 0.3500 & 0.5272 & \\
\hline Drumstick (Moringa oleifera) & 0.5200 & 0.8300 & \\
\hline
\end{tabular}

The result of the proximate and elemental analysis of four different leafy vegetables grown in Minna and its environs are shown in Tables 1 and 2. The results obtained in this study shows a close agreement with those found in literature (Oke, 1986). Thus, some of the difference in the chemical composition is not unexpected. Some of the factors might be linked to species, climate, growing conditions, nature of soil, application of natural or artificial manure and the period of analysis. From the experimental results, Talinum triangulare has the highest moisture (91.6\%) which might be due to large number of cell saps they posses. The results fall within the range of results reported by Tindall (1988) (90-93\%). They were all higher than the lowest range of results and lower than the highest range of results which may be due to the period of experimental work which was dry season. From Table 1, it was observed that vernonia amygdalina has the highest ash $(2.5 \%)$ which may be due to higher content of fibre and minerals in vernonia than all other vegetables. The values, obtained fall within the reported range of value by Sengupta, 1980. The results obtained for lipid analysis indicates that vernonia has the highest lipid content $(0.7 \%)(0.3-1.0$, Sengupta 1980) while moringa had the lowest $(0.2 \%)$ hence vernonia may be recommended for obese patients because of low lipid content. Moringa was found to have the highest protein content $(2.95 \%)$ which may be due to likely application of manure to enrich the nitrogen content of the soil where it was cultivated. All the vegetables except vernonia may be consumed for their moderate caloric value as can be observed from table 1 . Telfeiria had the highest vitamin $\mathrm{C}$ content. This is probably due to species analysed in this work, which has broad foliage leaves facilitating the reception of UV rays from sunlight with consequent acceleration of vitamin synthesis from glucose. The results fall within the range reported by Sengupta (1980). In Table 2, Moringa has the highest sodium content. All the values fall within the literature values (Fugile, 2000). Since leafy vegetables contain appreciable level of nutrients and are readily available, they could be consumed to supplement the scarce or nonavailable sources of nutrients.
Acknowledgement: The authors are grateful to the University and Department of Biochemistry for the facilities provided during the work.

\section{REFERENCES}

Alfred, D.; Patick, N. (1985). Integrated Food Science and Technology for tropics. $3^{\text {rd }}$ ed Mcmillan publishers. London Pp 293-300

Baker, E.M. Griffin, L. (1967). Vitamin C requirements in stress. Amer, J. Sci of Science 6.213-214.

Brain A. F; Allan G.C. (1986). Food science. A Chemical Approach, $15^{\text {th }}$ ed Edward Anold publishers Ltd London Pp 210-211

Fugile,L. (2000). Moringa, nature's medicine cabinet in Natural Nutrition for Tropics I. Sierra Sunrise Books Missouri p.9

Oke, L.O. (1988) Chemical Studies on commonly used leafy vegetables in Nigeria. J W/African Sci. Assll: 47-49

Oke, L.O; Ojofeitimi, O (1988). Nutrition for Nurses, tropical $2^{\text {nd }}$ ed health series. London group Ltd Pp 91-92.

Price, M. (1995) Moringa Tree in Natural Nutrition for Tropics 1. Sierra Sunrise Books Missouri Pp 12-15

Tindall, H.D. (1988) Vegetable in the Tropics. Mcmillan publisher, Hong Kong Pp 331-346.

Sengupta, SR; Pal, B (1980). Asssement of plant Nutrients.J. Sci. Agric 21:217-218. 